\title{
Analysis of Multicultural Education component In Textbooks
}

\section{R. Vafaei , M. Sobhaninejad (Ph.D.)}

Abstract: The present paper aims to investigate the amount of multi-cultural education components in the textbooks of secondary schools from 2013 to 2014 . It is conducted through text-analysis. The components of Multi-cultural education were initially collected from theoretical text and research background using document analysis and then they were numbered in the textbooks of secondary schools. The units of analysis were sentence, question, picture, activity, and the poem in the textbooks. Research tools were bibliography cards and inventory form in document and text analysis respectively. Data were analyzed by using population is the textbooks of secondary schools from 2013 to2014 and samples were Iran and International History I, Iran and International History II, History (PreUniversity Schools), Social Studies (Secondary Schools), Sociology I, Sociology which were expected to contain multicultural education components. The most significant results are as follows: out of 180 frequencies in the text books of secondary schools, History I with 76, i.e. $42.22 \%$ contained the most multi-cultural education components and Social Studies of secondary school with 5, i.e. $2.77 \%$ contained the least "introducing various cultures to students in the content of textbooks" had the largest number of frequencies, i.e. 59 and "helping to understand and tolerate different opinions from various cultures, and defining multiculture homework for students in the content of textbooks" had the smallest one, only 1 , i.e. $0.55 \%$.

Key words: Multicultural Education, Text-analysis, Textbooks, Secondary schools. descriptive statistics. The statistical II, Social Studies (Pre-University Schools) components. Among the components,

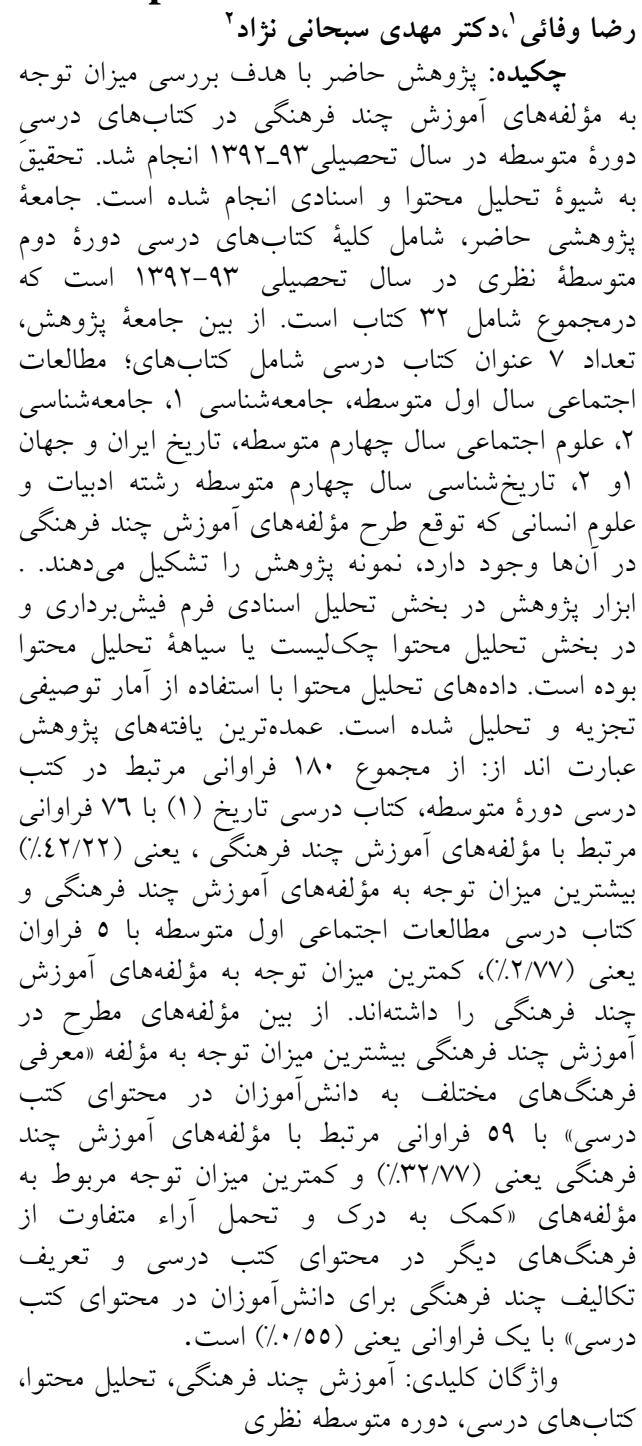

vafaeireza10@gmail.com 


\section{مقدمه}

در عصر حاضر به دليل تعاملات گسترده فيزيكى و مجازى افراد و فرهنخها و از ميان رفتن

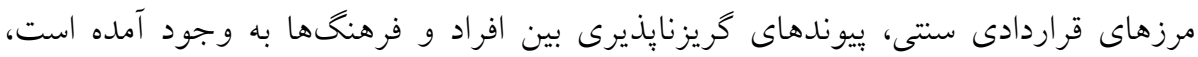

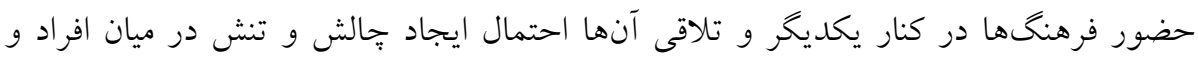

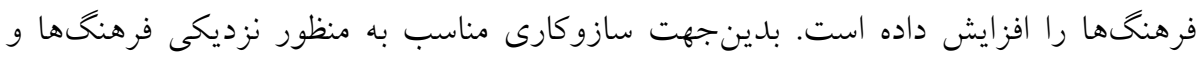

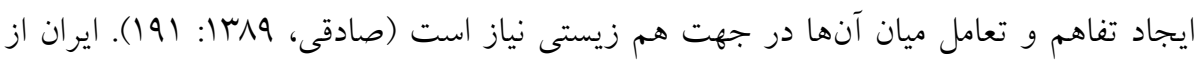

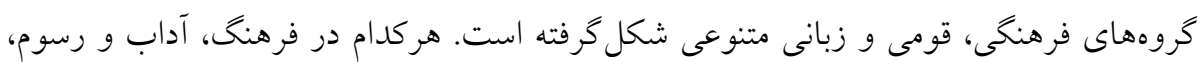

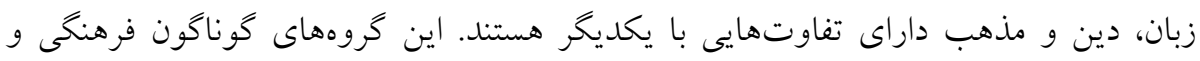

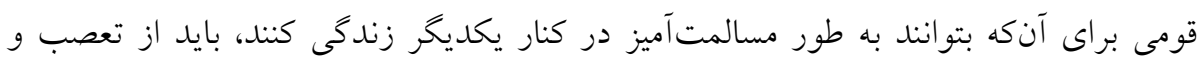

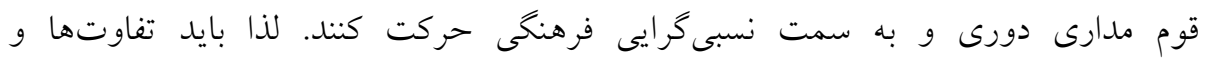

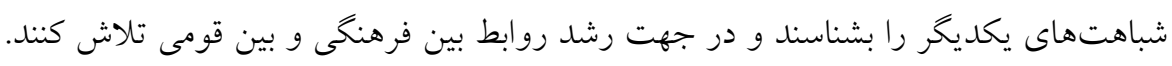

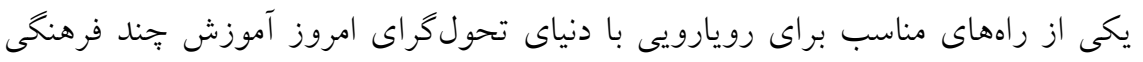

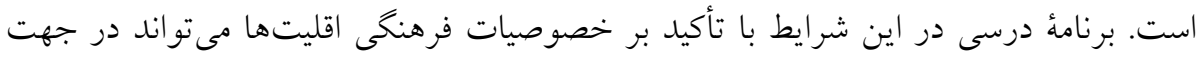

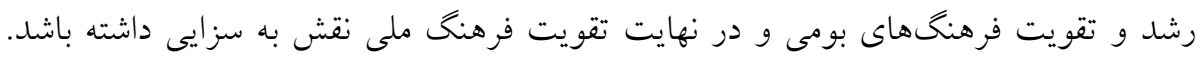

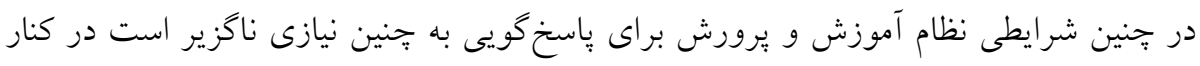

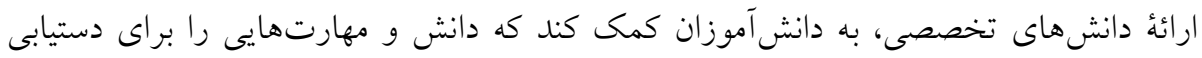

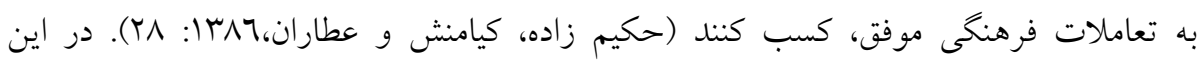

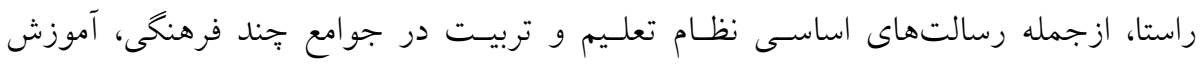

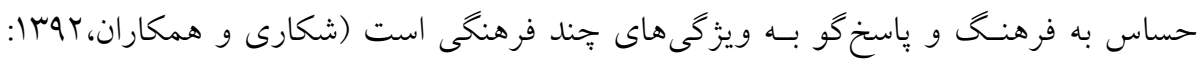

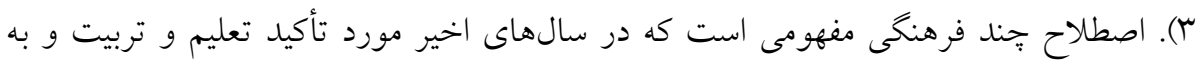

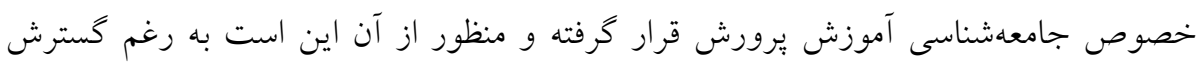

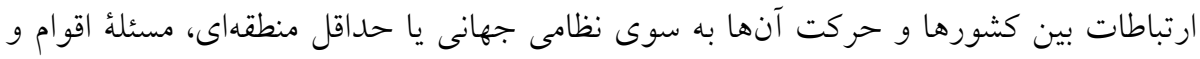

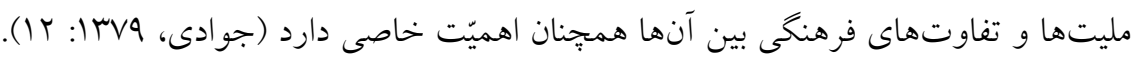


مؤلفههاى آموزش جند فرهنگى و تحليل آن در...

به عقيدة بنكس' "آموزش جند فرهنكى" نوعى رويكرد آموزشى است كه تنوع قومى و

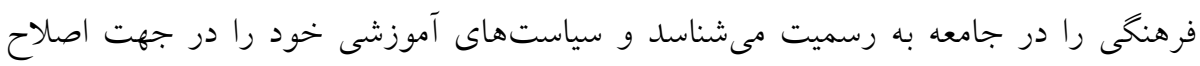

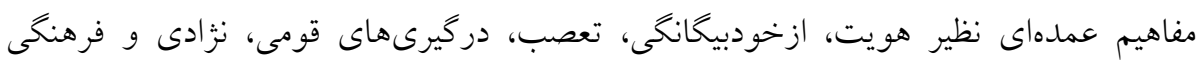

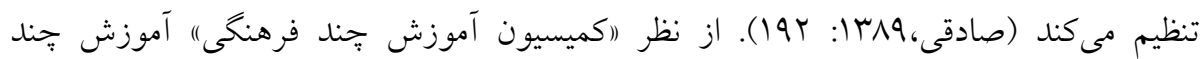

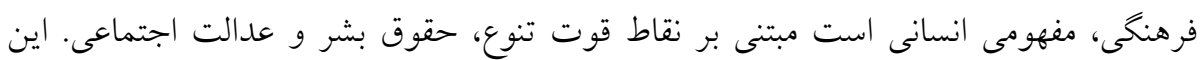

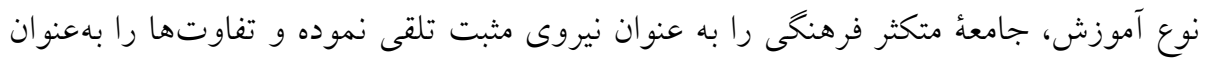

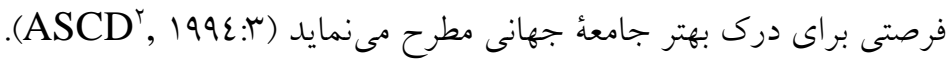

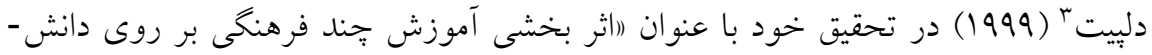

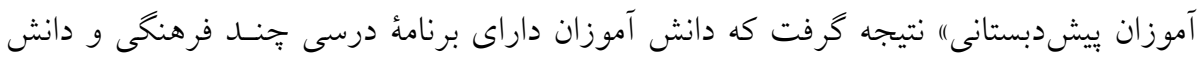

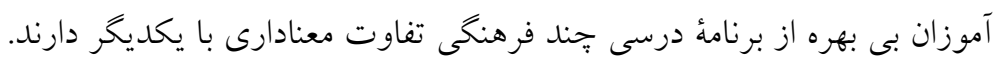

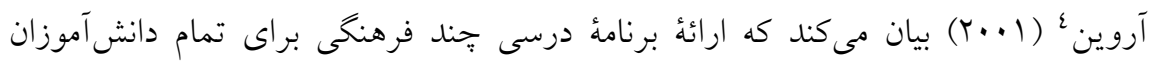

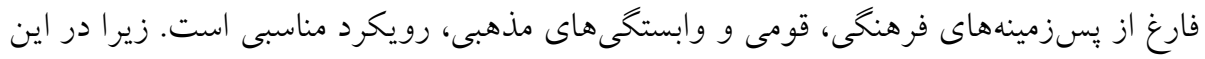

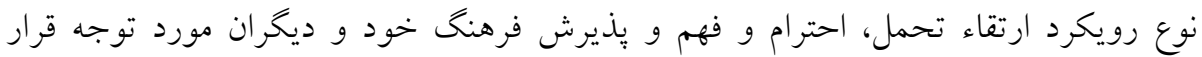
مى گيرد.

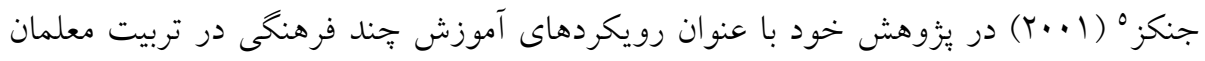

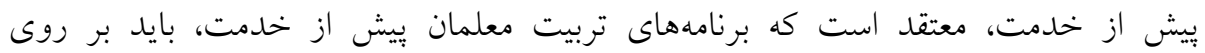

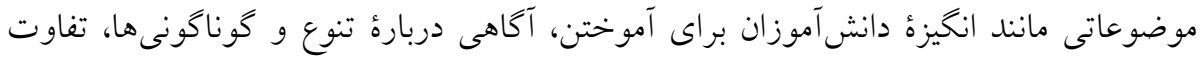

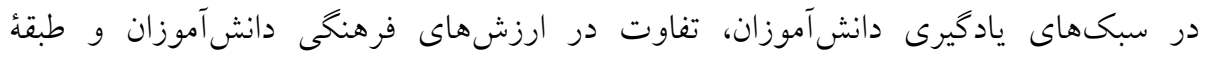
اجتماعى آنان حساس باشند.

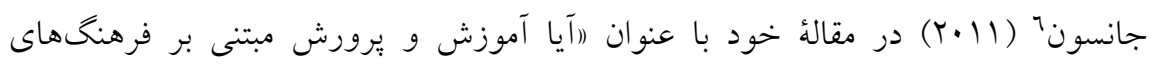
مختلف باعث بهبود نخرش دانش آموزان نسبت به نزادهاى گوناكون مىشود؟؟) به به اين نتيجه

1- Baks

2- Association for Supervision and Curriculum Development

3- Delpit

4- Arvin

5- Jenks

6- Johnson 
رسيد كه كودكانى كه تحت آموزش مبتنى بر فرهنگهاى متفاوت قرار مى گيرند كمتر به خاطر اختلافات و تفاوتهاى نزادى آسيب مى مبينند.

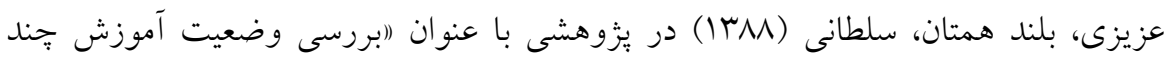

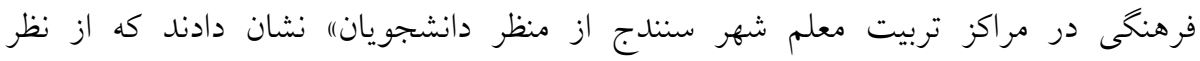

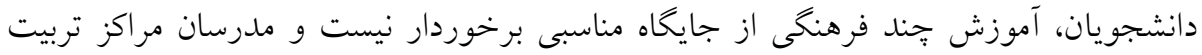

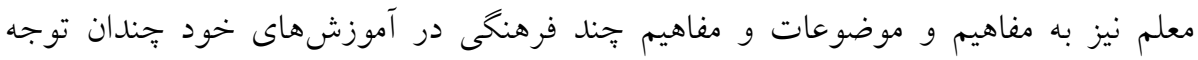

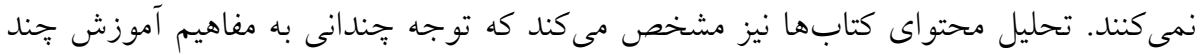

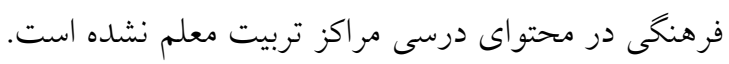

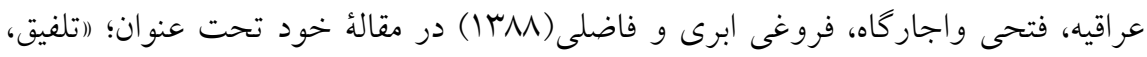
راهبردى مناسب براى تدوين برنامة درسى جند فرهنگى" با ذكر اين نكته كه بسيارى از كشورها مانند ايران، بلطور مستقيم دركير تنوع اقوام و فرهنخهاى مختلف هستند، وظيفه

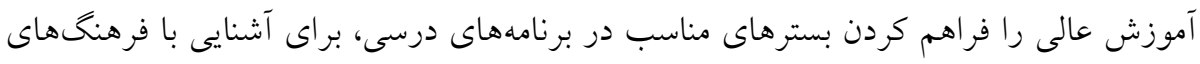
مختلف بيان مى كنند.

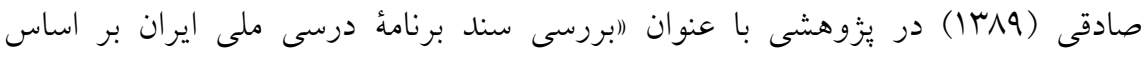

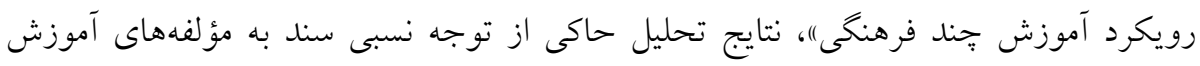
جند فرهنكى است. صادقى (1) (1) در مقالة خود با عنوان (اتبيين ويزگكىها و ضرورتهاى تدوين برنامةٔ درسى

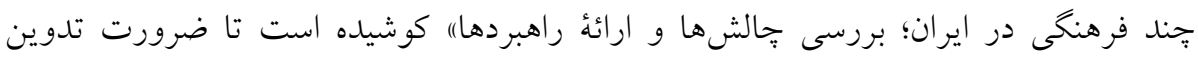

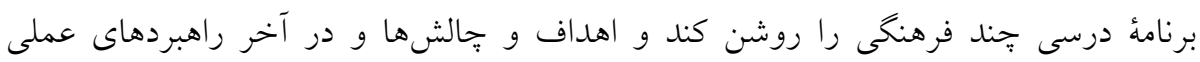

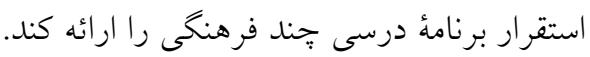

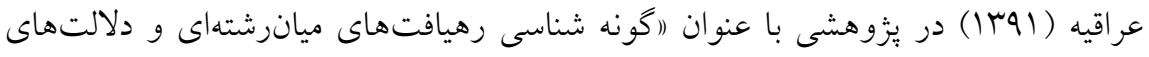

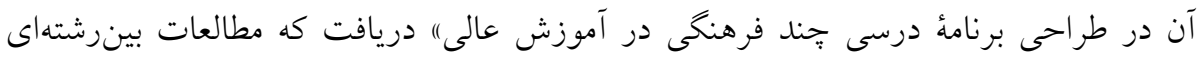

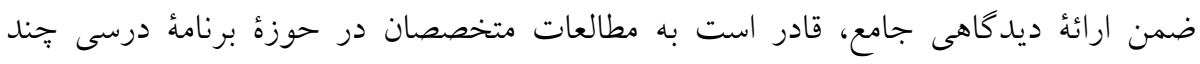

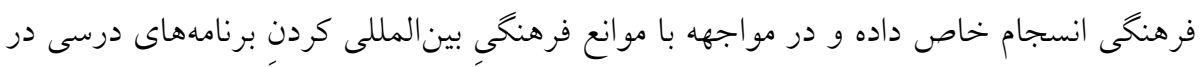
آموزش عالى، نقش مؤثرى را ايفا نمايد. 
مؤلفه هاى آموزش جند فرهنگى و تحليل آن در...

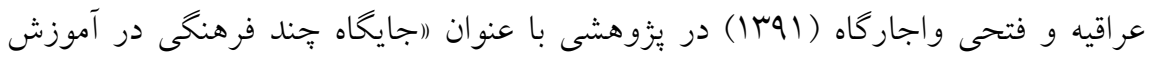

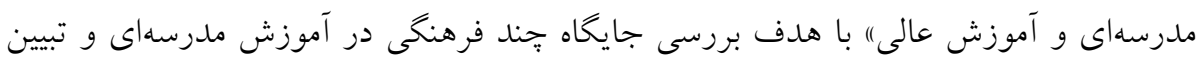

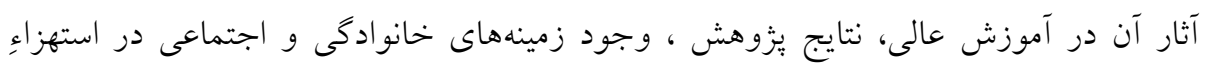

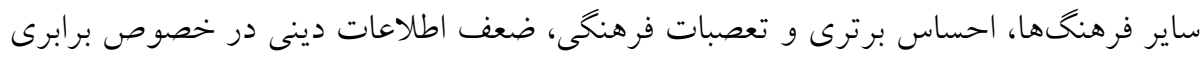

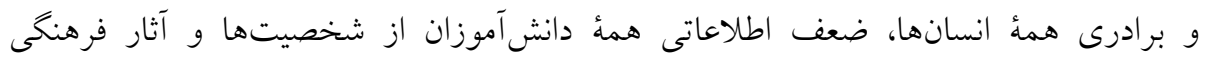

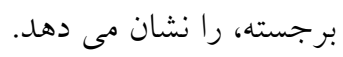

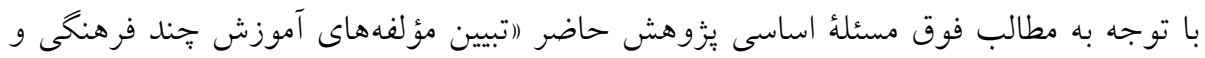

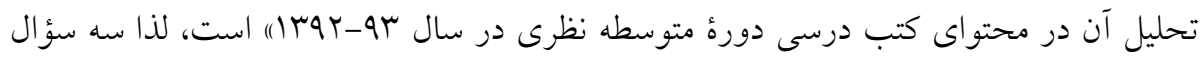

$$
\text { ذيل طرح و مورد بررسى واقعشدهاند. }
$$

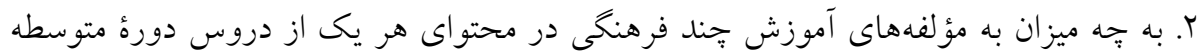
نظرى توجه شده است؟ ب. رتبهبندى ميزان توجه كتابهاى درسى دورهُ متوسطه نظرى به مؤلفههاى آموزش جنه

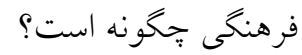

يُزوهش حاضر به روش تحليل اسنادى و تحليل محتوا' انجام شده است. ابتدا مؤلفههاى

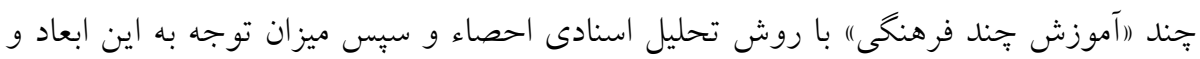
مؤلفهها در كتابهاى درسى دورةٌ متوسطه مورد بررسى قرار كرفت. جامعةُ يزوهشى حاضر،

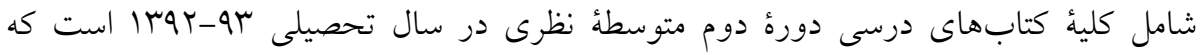

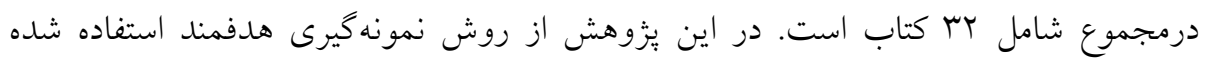

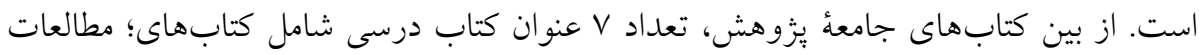

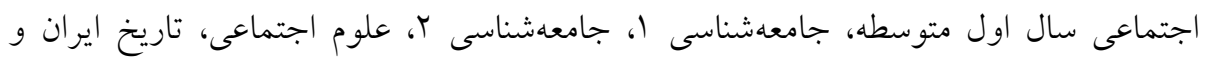

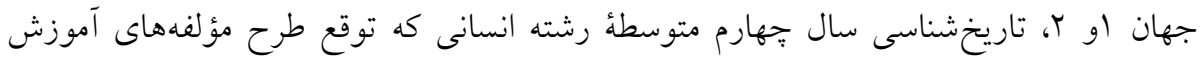

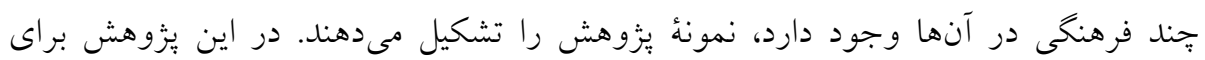


تحليل اسنادى جهت احصاء مؤلفهاى آموزش جنند فرهنگى از بركهاى فيشبردارى استفاده شده است.

همجنين در اين يزّوهش براى بررسى و تحليل محتواى كتابهاى درسى دوره متوسطه نظرى از نظر ميزان توجه به مؤلفههاى مطرح در آموزش جند فرهنكى از سياهه تحليل محتواى محقق ساخته، استفاده شده است. به منظور تدوين سياهه تحليل محتواى كتابهاى درسى ابتدا، تعداد قابل توجهى از منابع نظرى و يزوهشى مرتبط در حوزههاى آموزش جند فرهنگى بررسى و مؤلفههاى مرتبط از آنها استخراج شد؛ ابزار داراى بيست و جهار مؤلفه است. براى حصول اطمينان از روايى صورى و محتوايى از نظر متخصصان استفاده شده است، بهاينترتيب كه فرم اوليه تحليل محتوا كه شامل كلية مؤلفههاى آموزش جند فرهنكى، در اختيار تعدادى از صاحبنظران براى تغيير و اصلاح قرار كرفت كه يس از اعمال نظرات آنها سياهـ تحليل محتوا با بيستوجهار مؤلفه تهيه گرديد. به منظور حصول اطمينان از وجود پيايايى از روش ويليام اسكات استفاده گرديد. به اين صورت كه بخشى از محتواى كتب توسط محقق و تحليل گر محتواى و متخصص ديخرى، تحليل شد كه ضريب توافق حاصل سو/ • به دست آمد. براى تجزيه و تحليل دادهها از شاخصهاى آمارى توصيفى استفاده شده است. در قسمت توصيفى از جداول و نمودارها براى توصيف فراوانى هر كتاب، فراوانى هر مؤلفه در همدٔ كتابها، درصد مورد مشاهده، استفاده شده است. در هر بند، تصاوير، برسش، تمرين و جدول به محض مشاهده يكى از شواهد و مضامين معنى دار مربوط، كد آن در جدول علامت زده شده و يك بار فراوانى براى آن منظور شد و از روى اين فراوانىها محتواى كل كتابها مورد يردازش، توصيف و تحليل قرار گرفت.

يافته ها

\section{1 - مؤلفههاى آموزش جّند فرهنگى كدماند؟}

با توجه به اينكه هدف يزوهش حاضر شناسايى مؤلفههاى آموزش جند فرهنكى در محتواى برنامه درسى دورهُ متوسطه) است، بنابراين يُ از مطالعه و بررسى ادبيات و بيشينه

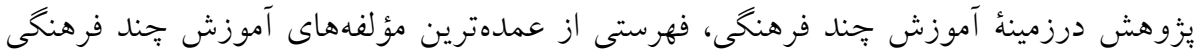
تهيه شد و در اختيار متخصصان حوزهٌ مذكور قرار گرفت و يس از جند مرتبه بررسى و اصلاح و نهايتاً تأييد آنها توسط متخصصان، اين نتيجه به دست آمد كه مؤلفههاى قابل بررسى در 
محتواى برنامهُ درسى را مىتوان به بيستوجهار مؤلفه در نظر كرفت كه جدول ذيل تهيّه و به

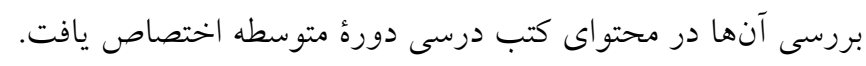

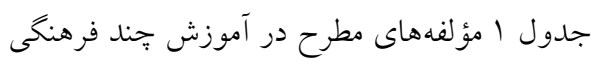

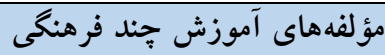

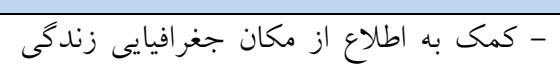
بيروان اديان و مذاهب مختلف دران در محتوان كتب درسى - انعكاس نواحى جغرافيايى مربوط به اقوام مختلف در محتواى كتب درسى أنى

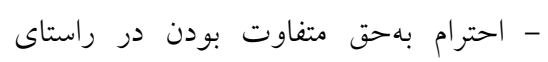

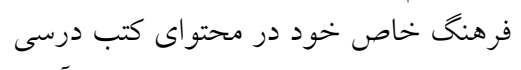

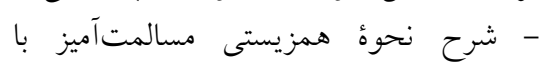
كروههاى ديخر در محتواى كتب درسى ندئ

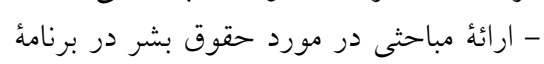

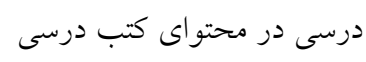

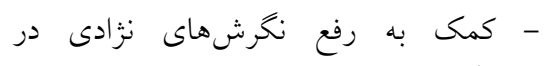

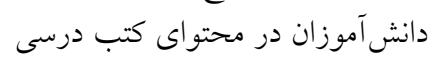

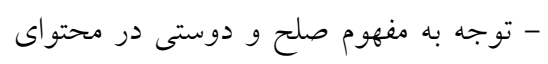

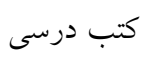
- احترام بهحق حفظ زبان قومى براى اقليتها در محتواى كتب درسى احتى بلى

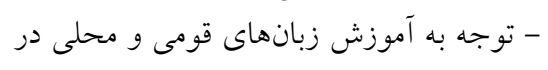

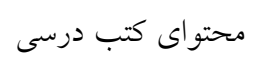

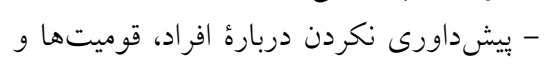

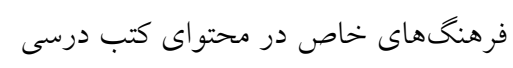

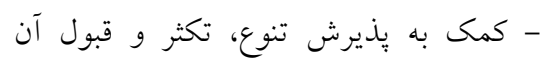

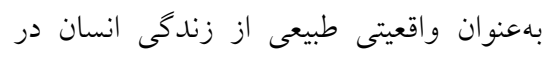
محتو اى كتب درسى وتعن

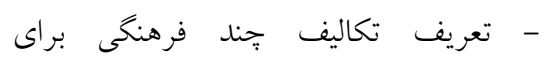
دانش آموزان در محتواى كتب درسى تكاليف

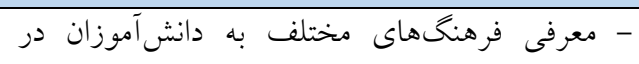
محتو اى كتب درسى

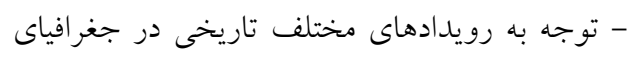

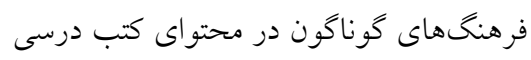

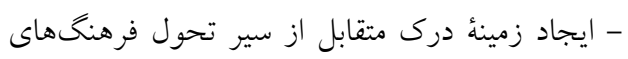

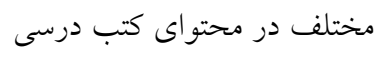
توجه به تفاوتهاى فرهنكى اقوام در محتواى كتب دردي

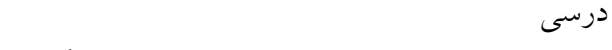
- كمك به درك و بهبود ارتباطهاى بين فرهنكى در

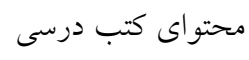

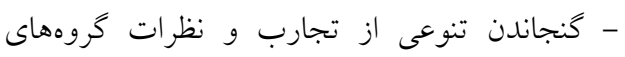

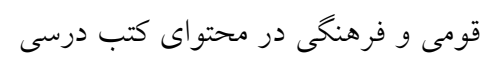

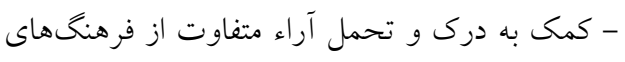
ديخر در محتواى كتب درسى بهى درى

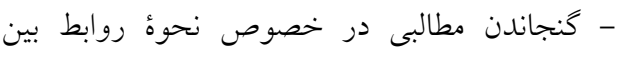

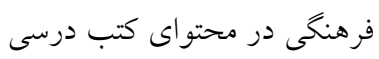

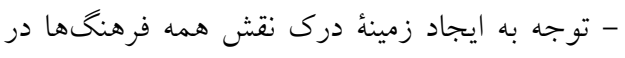
شكل گيرى تمدن و توليد دانش در محتواى كتب - كمكى به درى و احترام به اديان و مذاهب گوناگون در محتواى كتب درسى

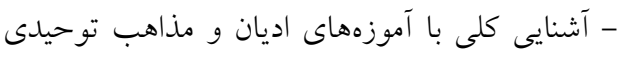
در محتواى كتب درسى

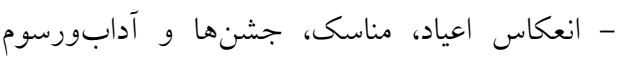
مرتبط با اقليتهاى فرهنكى در محتواى كتب درسى أنى 
Y- به جهه ميزان به مؤلفهاى آموزش جند فرهنگى در محتواى هر يك از دروس دوره متوسطة نظرى توجه شده است؟ Y-1- تحليل محتواى كتاب درسى تاريخ ايران و جهان ا سال دوم متوسطه

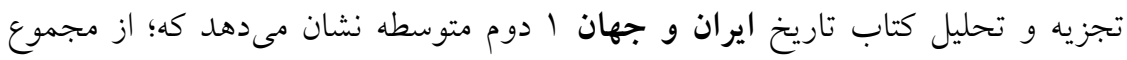

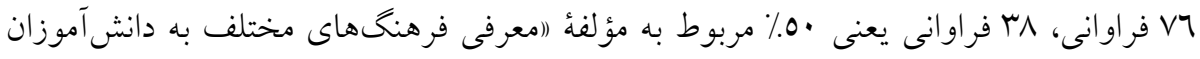

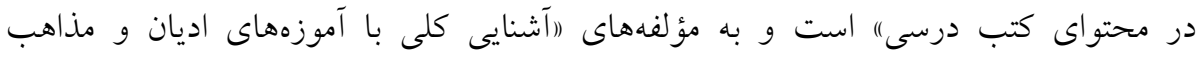

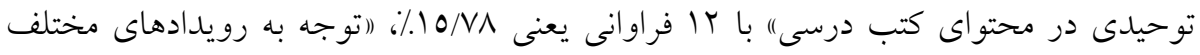

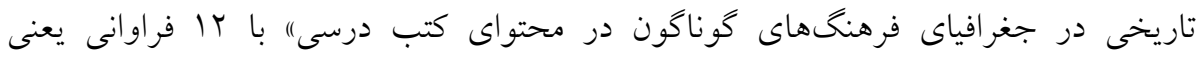

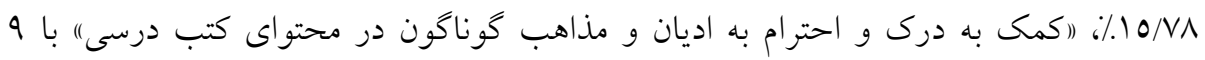

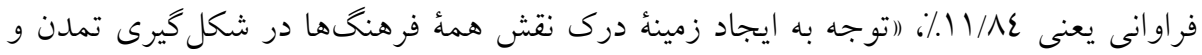

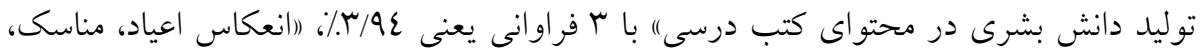

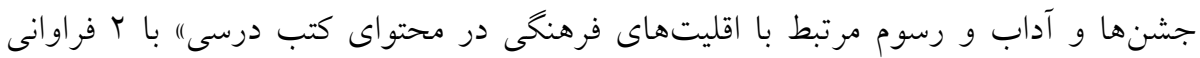

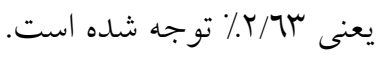

\begin{tabular}{|c|c|c|c|}
\hline \multicolumn{2}{|c|}{ نوع اشاره } & درصد از فراوانى كل & فراوانى مؤلفهها \\
\hline غيرمستقيم & مستقيم & & \\
\hline 10 & 71 & $\%$ \% & V7 \\
\hline
\end{tabular}

r-Y-r تحليل محتواى كتاب درسى تاريخ ايران و جهان r سال سوم متوسطه تجزيه و تحليل كتاب درسى تاريخ ايران و جهان r سوم متوسطه نشان مىدهد كه از ليران

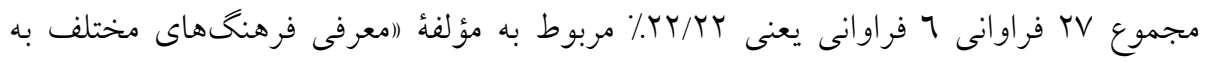

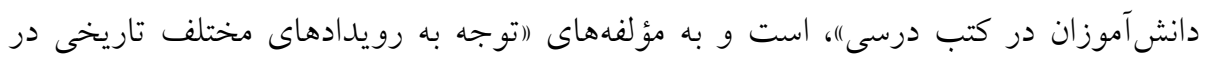

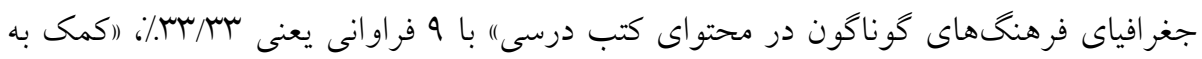

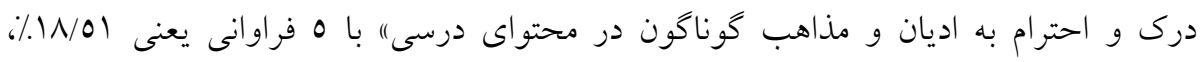

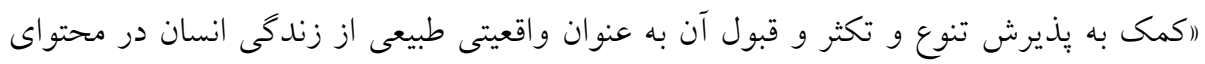

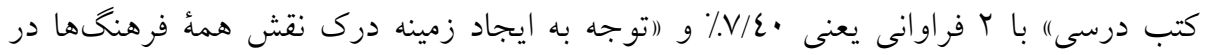

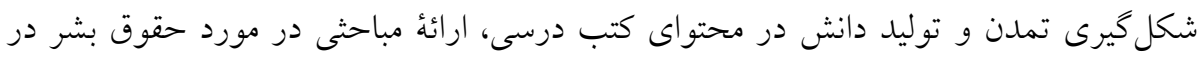


مؤلفههاى آموزش جند فرهنگى و تحليل آن در...

محتواى كتب درسى، احترام به حق حفظ زبان قومى براى اقليتهاى فرهنكى، انعكاس اعياد،

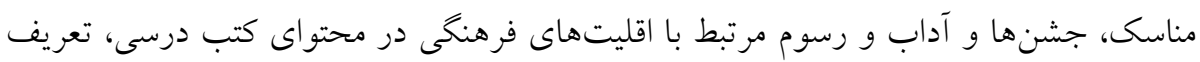

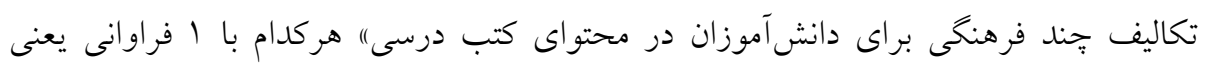

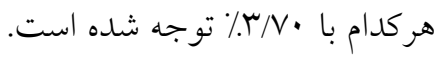

\begin{tabular}{|c|c|c|c|}
\hline \multicolumn{2}{|c|}{ نوع اشاره } & درصد از فراوانى كل & فراو انى مؤلفهها \\
\hline غيرمستقيم & مستقيم & & \\
\hline 1. & IV & $\% 10$ & TV \\
\hline
\end{tabular}

r-r-r تحليل محتواى كتاب درسى تاريخشناسى ييشدانشخاهى

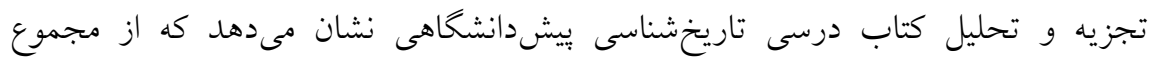

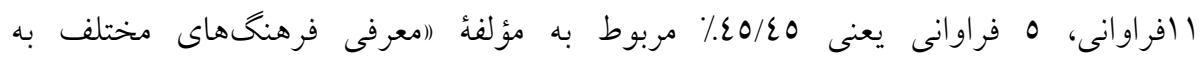

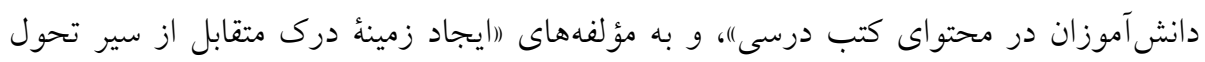

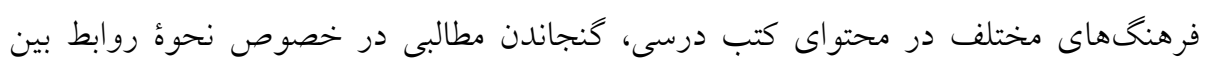

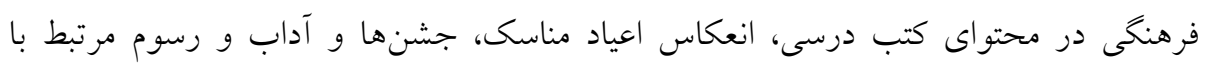

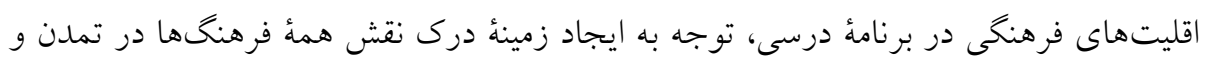

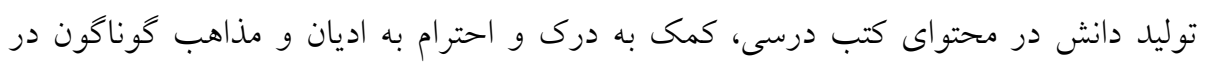

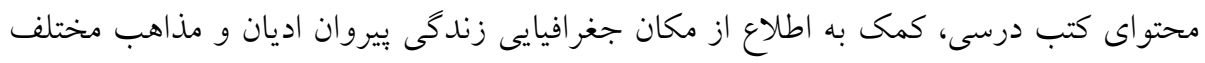

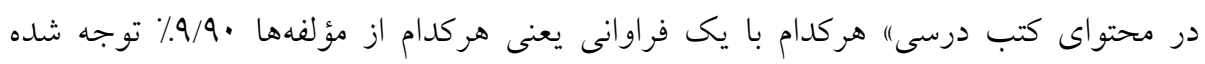

\begin{tabular}{|c|c|c|c|}
\hline \multicolumn{2}{|c|}{ نوع اشاره } & درصد از فراوانى كل & فراوانى مؤلفهها \\
\hline غيرمستقيم & مستقيم & & \\
\hline$\wedge$ & $r$ & $\% 7,11$ & 11 \\
\hline
\end{tabular}


Y_عـ تحليل محتواى كتاب درسى مطالعات اجتماعى اول متوسطه تجزيه و تحليل كتاب مطالعات اجتماعى اول متوسطه نشان مىدهد كه از مجموع 0 فراوانى ץ فراوانى يعنى •عـ/ مربوط به مؤلفهُ (اكمك به يذيرش تنوع و تكثر و قبولان بهعنوان و اقعيتى طبيعى از زندكى انسان در محتواى كتب درسى)، و به مؤلفههاى (ارائهُ مباحثى در مورد حقوق بشر در محتواى كتب درسى) با ب فراوانى يعنى •ع.٪ة ("كمك به درك و تحمل آراء متفاوت از فرهنخ هاى ديخر در محتواى كتب درسى") با ا فراوانى يعنى ، ب٪٪ توجه شده است.

\begin{tabular}{|c|c|c|c|}
\hline \multicolumn{2}{|c|}{ نوع اشاره } & درصد از فراوانى كل & فراوانى مؤلفهها \\
\hline غير مستقيم & مستقيم & & \\
\hline r & $r$ & $\%, \mathrm{~T}, \mathrm{~V}$ & 0 \\
\hline
\end{tabular}

Y-0- تحليل محتواى كتاب درسى جامعه شناسى ا دوم متوسطه

تجزيه و تحليل كتاب جامعهشناسى | دوم متوسطه نشان مىدهد كه از مجموع 11 فراوانى 0 فراوانى يعنى TV/VV٪ مربوط به مؤلفة (امعرفى فرهنخ هاى مختلف به دانش آموزان در محتواى كتب درسى") و به مؤلفههاى (كمك به بذيرش تنوع و تكثر و قبول آن به عنوان

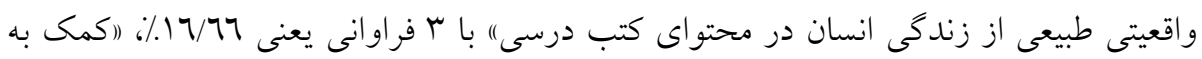
درى و احترام به اديان و مذاهب كوناكون در محتوا كتب درسى" با ب فراوانى يعنى ||/1/ و "اتوجه به مفهوم صلح و دوستى در برنامd درسى، توجه به ايجاد زمينه درى نقش همه فرهنگها در شكل گيرى تمدن و توليد دانش، انعكاس نواحى جغرافياى مربوط به اقوام مختلف در كتب درسى، انعكاس نواحى مختلف جغرافيايى مربوط به اقوام مختلف در كتب درسى، توجه به تفاوتهاى فرهنكى اقوام در كتب درسى، احترام به حق حفظ زبان قومى براى اقليتها در محتواى كتب درسى، آشنايى كلى با آموزههاى اديان و مذاهب توحيدى در محتواى كتب درسى، گنجاندن مطالبى در خصوص نحوهُ روابط بين فرهنگى در محتواى كتب درسى" هركدام با ا فراوانى يعنى هر كدام 0/00\% توجه شده است.

\begin{tabular}{|c|c|c|c|}
\hline \multicolumn{2}{|c|}{ نوع اشاره } & درصد از فراوانى كل & فراوانى مؤلفهها \\
\hline غير مستقيم & مستقيم & & \\
\hline $1 \varepsilon$ & $\varepsilon$ & $\% 1$. & 11 \\
\hline
\end{tabular}


مؤلفهاى آموزش جند فرهنگى و تحليل آن در...

Y-7 - تحليل محتواى كتاب درسى جامعهشناسى Y سوم متوسطه

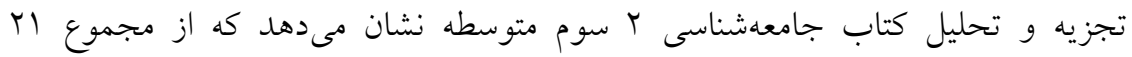

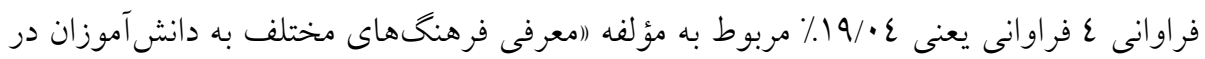

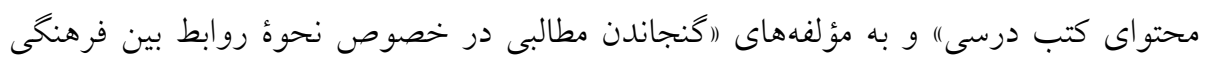

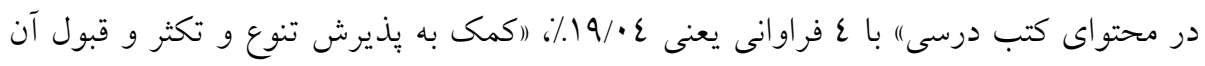

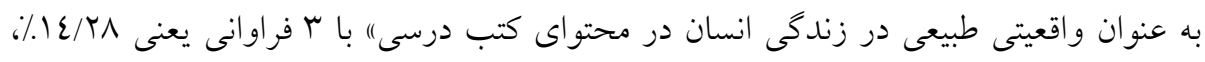

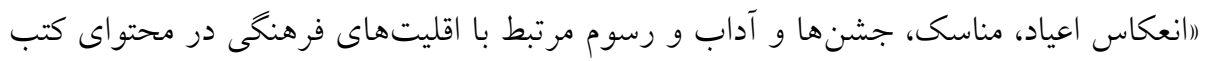

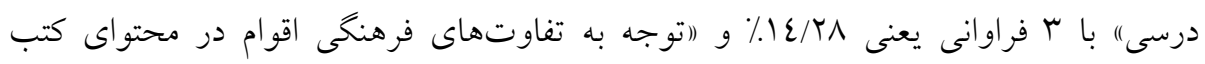
درسى، توجه به مفهوم صلح و دوستى در برنامئ درسى" هركدام با ب فراوانى يعنى هركدام

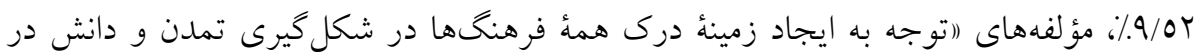

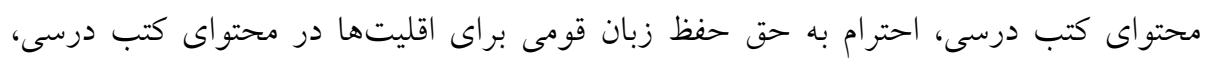

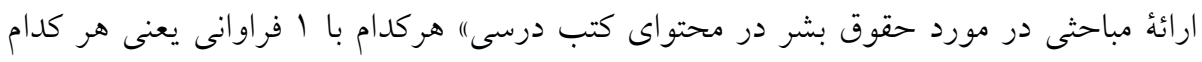

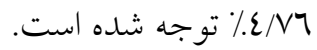

\begin{tabular}{|c|c|c|c|}
\hline \multicolumn{2}{|c|}{ نوع اشاره } & درصد از فراوانى كل & فراوانى مؤلفهها \\
\hline غيرمستقيم & مستقيم & & \\
\hline Ir & 9 & $\% 11,77$ & $r$ \\
\hline
\end{tabular}

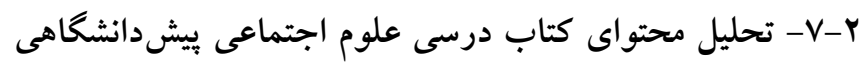

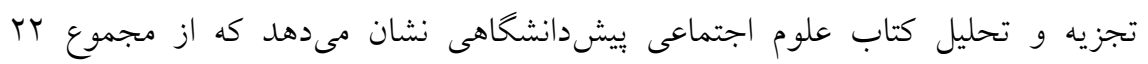

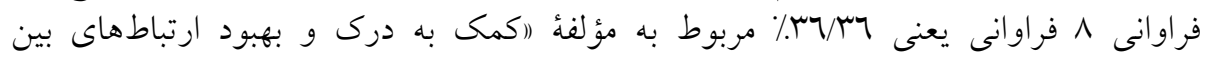

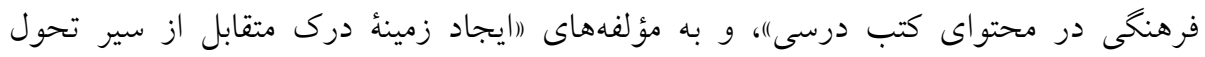

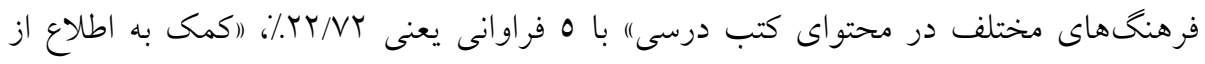

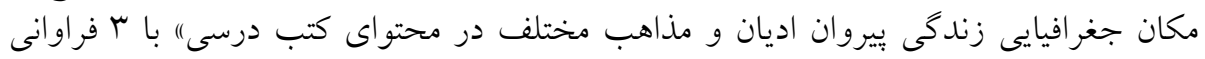

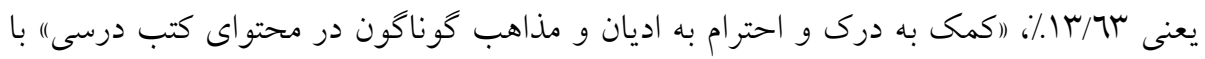

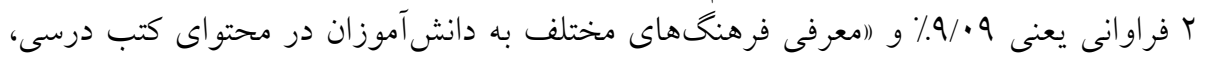

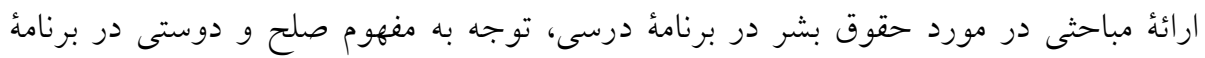

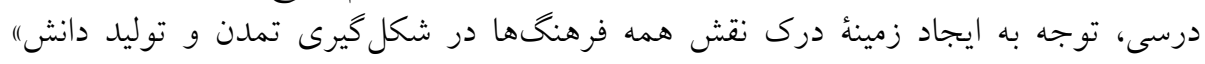

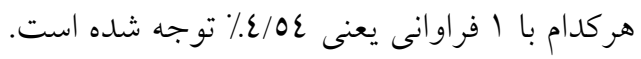




\begin{tabular}{|c|c|c|c|}
\hline & نوع اشاره & درصد از فراوانى كل & فراوانى مؤلفهها \\
\hline غيرمستقيم & مستقيم & \multirow[b]{2}{*}{$\% M, Y Y$} & \multirow[b]{2}{*}{ Tr } \\
\hline 1. & IT & & \\
\hline
\end{tabular}

بـ ر رتبهبندى ميزان توجه كتابهاى درسى دورهُ متوسطه نظرى به مؤلفهاى آموزش جند

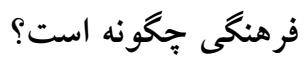
از مجموع •11 فراوانى شامل عبارتها، مضمونها، مثالها، موضوعهاى درسى، كلمهها،

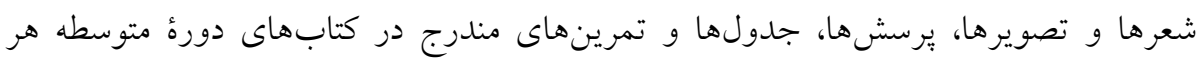

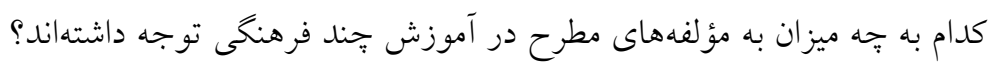

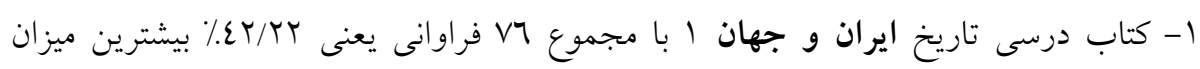

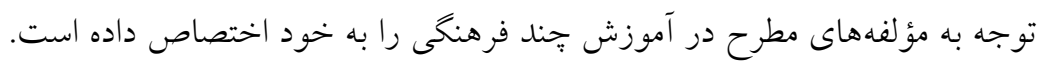

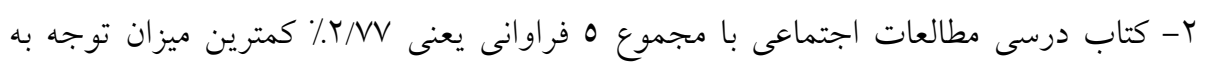

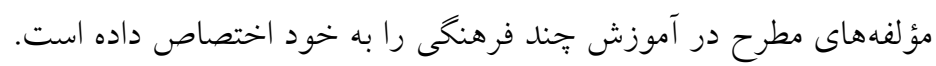

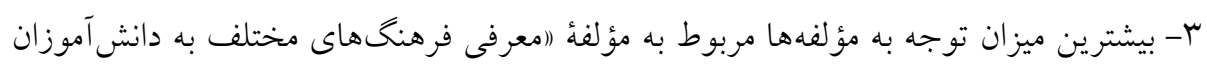

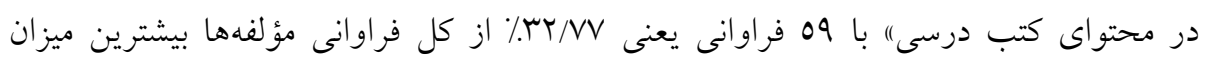
توجه را به خود اختصاص داده است.

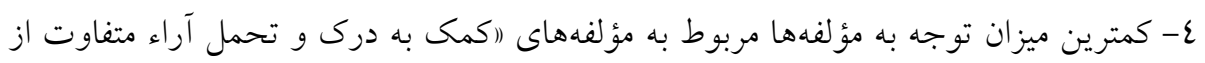

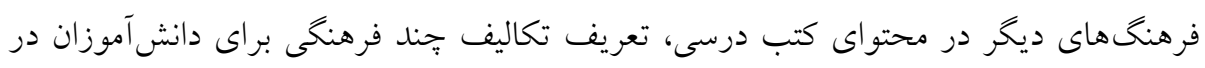

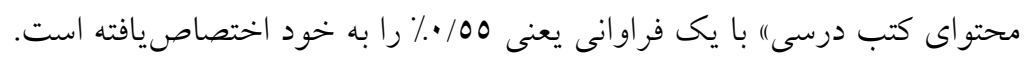

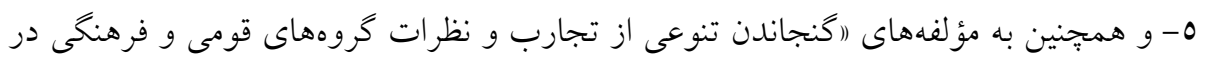

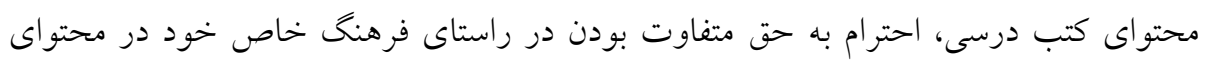

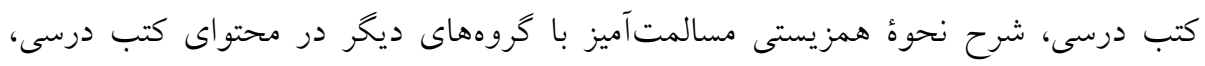

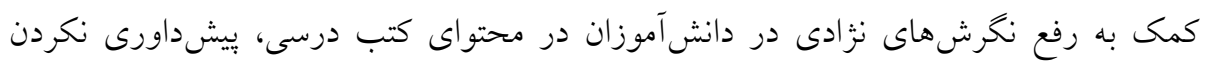

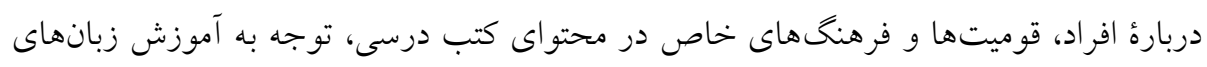
قومى و محلى در محتواى كتب درسى" در هيج يكى از كتابها توجه نشده است. 
مؤلفهاى آموزش جند فرهنگى و تحليل آن در...

جدول O-Y-Y- جمعبندى نهايى ميزان توجه به مؤلفههاى آموزش جند فرهنگ در كتابهاى دوره متوسطة نظرى

\begin{tabular}{|c|c|c|c|}
\hline درصد توجه & 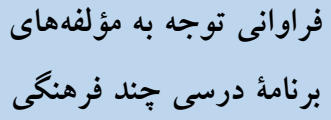 & عنوان كتاب & رديف \\
\hline$\% Y / V V$ & 0 & مطالعات اجتماعى & 1 \\
\hline$\%$. & 11 & جامعهشناسى 1 & r \\
\hline$\% 11 / 77$ & $r_{1}$ & جامعهشناسى Tr & r \\
\hline$\%$ IY YY & rr & علوم اجتماعى & $\varepsilon$ \\
\hline$\%$ $/$ IYYY & vi & تاريخ ايران و جهان 1 & 0 \\
\hline$\% 10$ & PV & تاريخ ايران و جهان r & 7 \\
\hline$\% .7 / 11$ & 11 & تاريخشناسى & v \\
\hline$\% 1$. & $1 \wedge$. & 米米米米米 & جموع \\
\hline
\end{tabular}

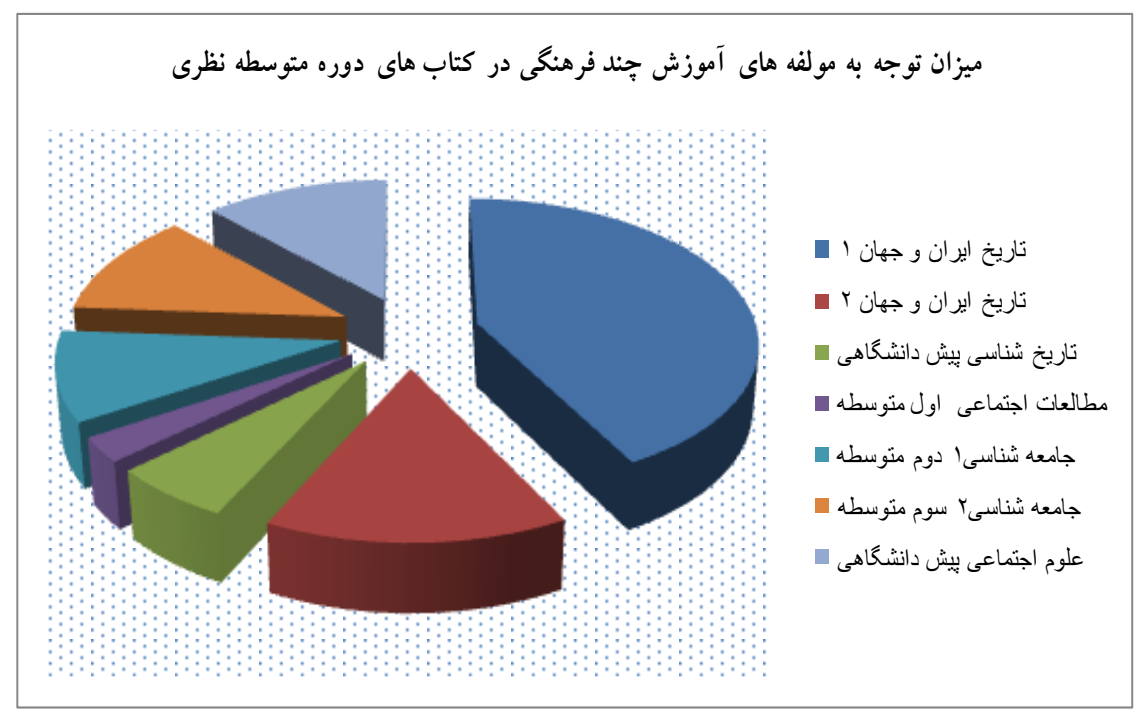

نمودار شماره 0- ا - بررسى ميزان سهم هر كتاب از مؤلفههاى برنامة درسى جند فرهنگى 


\section{بحث و نتيجه گيرى}

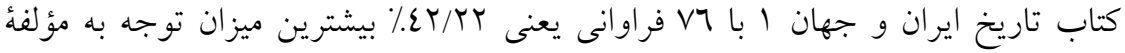

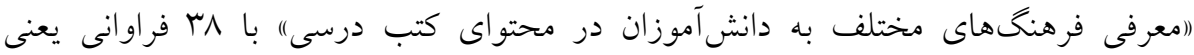

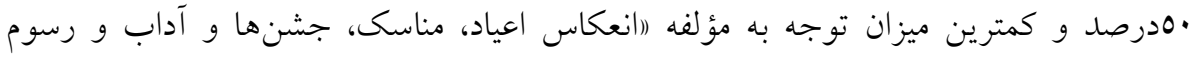

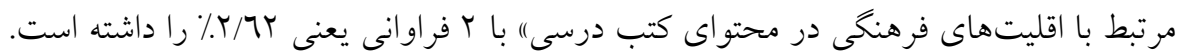

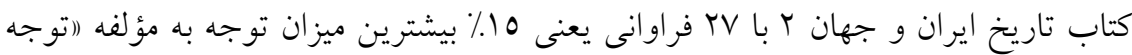

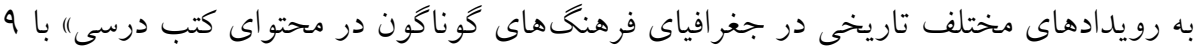

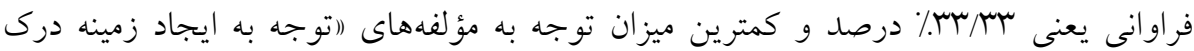

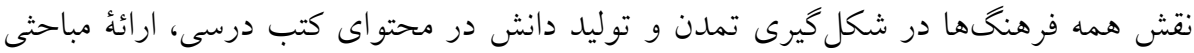

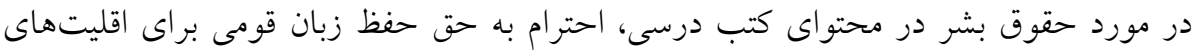

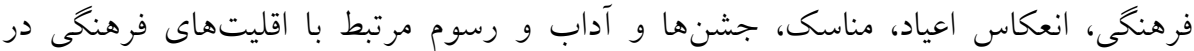

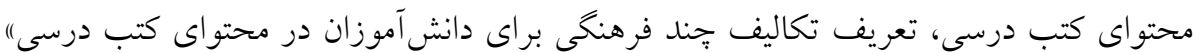
هركدام با ا فراوانى يعنى •/T/\%٪ را داشته است.

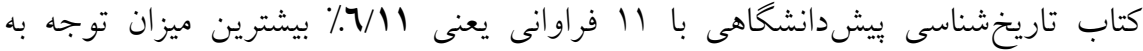

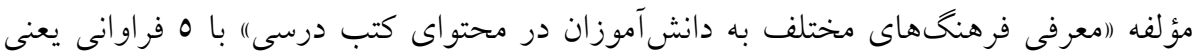

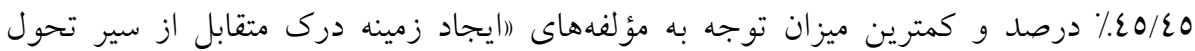

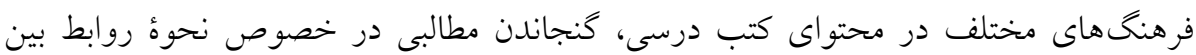

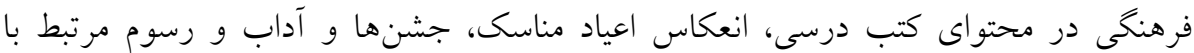

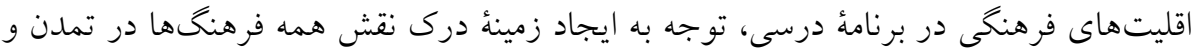

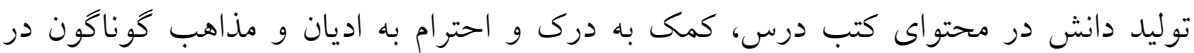

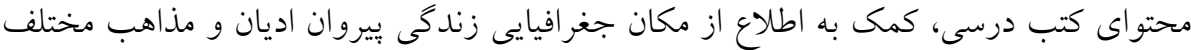

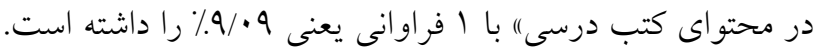

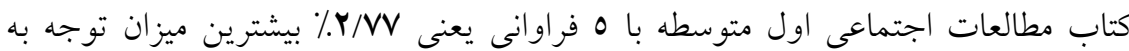

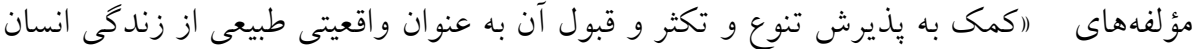

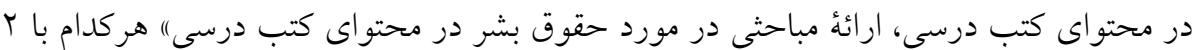

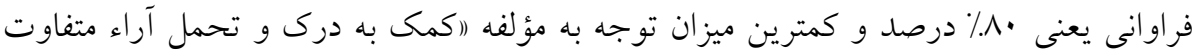

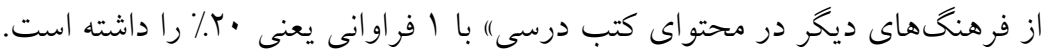

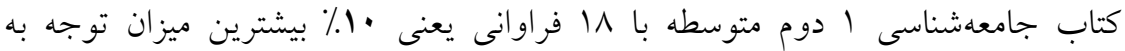

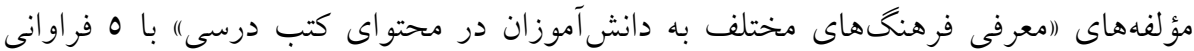


يعنى TV/VV و ومترين ميزان توجه به مؤلفه (اتوجه به مفهوم صلح و دوستى در برنامة درسى،

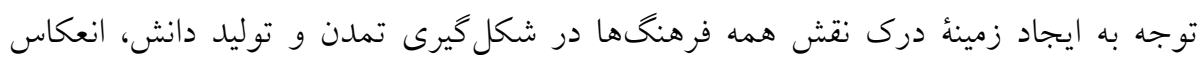

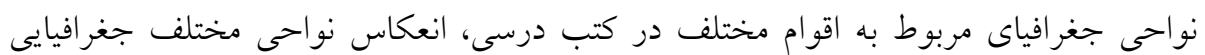

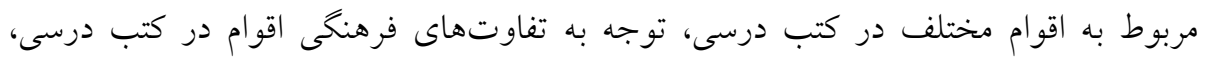

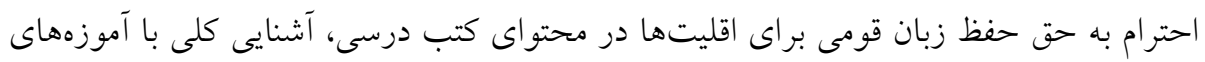

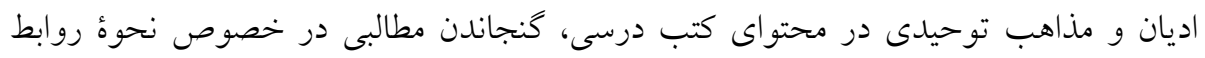

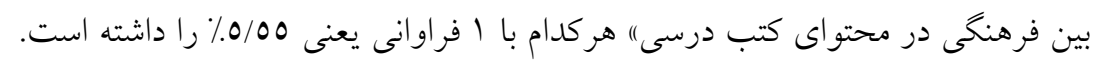

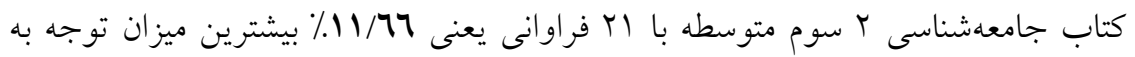

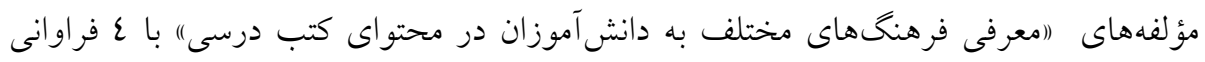

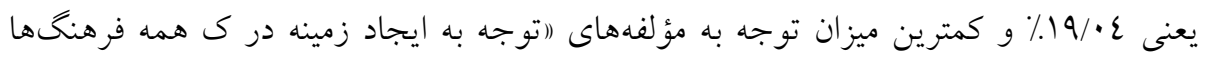

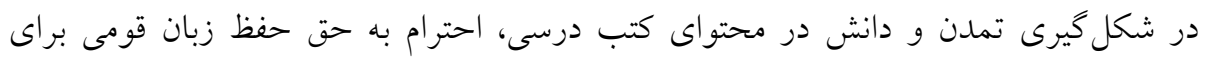

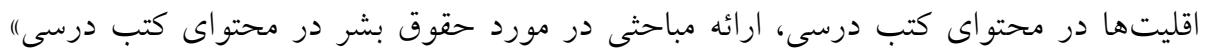

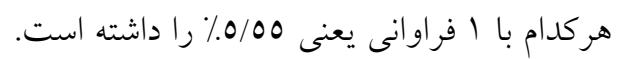

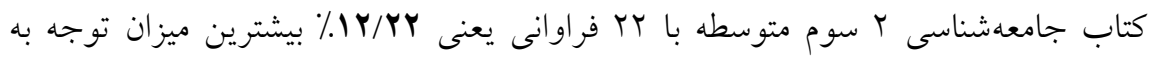

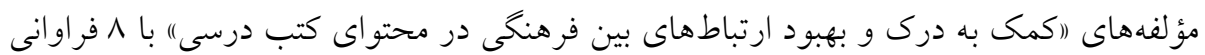

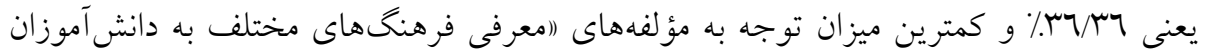

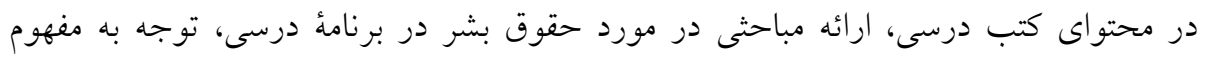

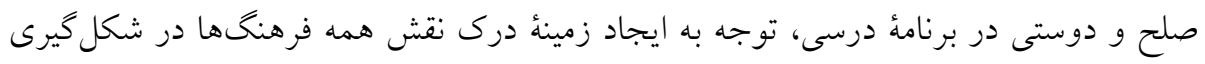

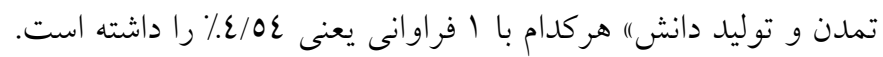

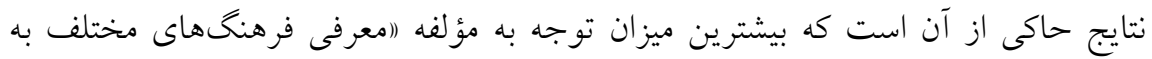

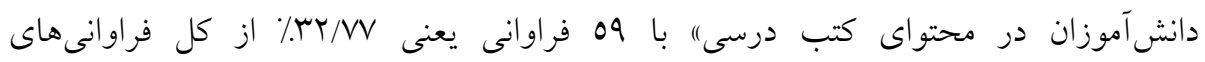

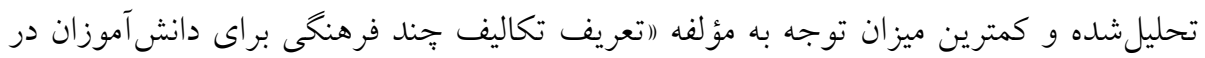

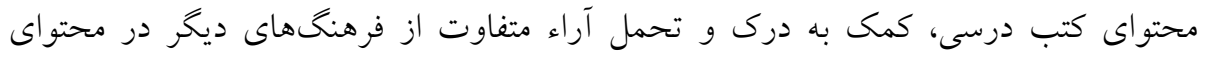

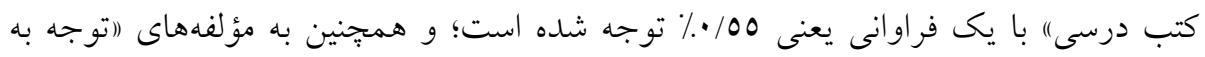

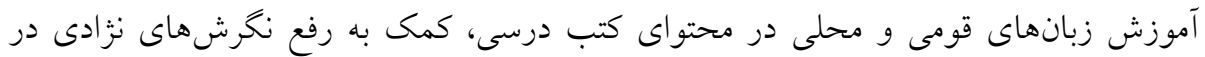

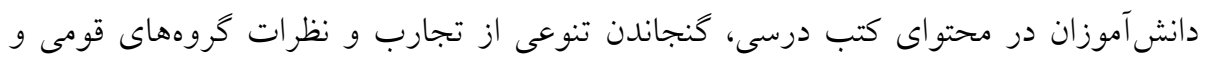

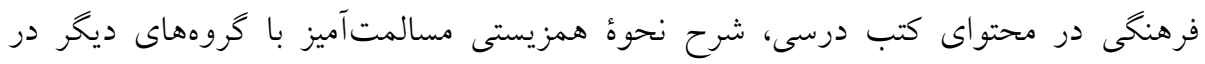

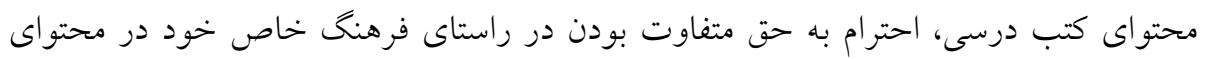


كتب درسى، ييشداورى نكردن درباره افراد، قوميتها و فرهنگهاى خاص در محتواى كتب درسى" در كتابهاى مورد بررسى توجه نشده است.

\section{يُشنهادهاى عملمى جهت كاربست يافته هاى يُوهش}

آموزش جند فرهنكى و تأكيد كتابهاى درسى بر اين موضوع مقولهاى بسيار مهم به شمار

مى آيد؛ بنابراين بيشنهاد مى كردد:

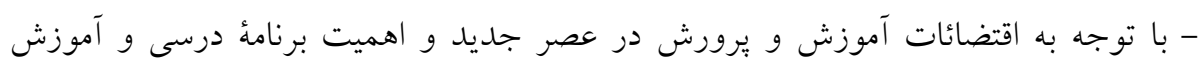
جند فرهنگى و لزوم همخوانى بيشتر كتابهاى درسى، گروههاى متفاوت تأليف كتب درسى بـى

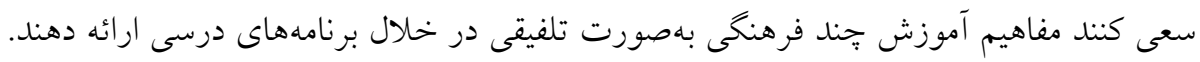

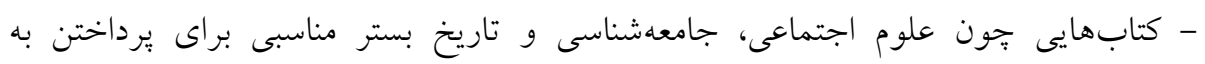

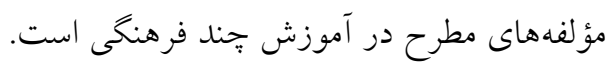

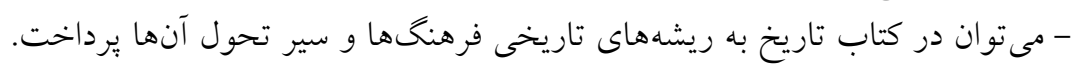
- با توجه به ماهيّت كتابهاى علوم اجتماعى، جامعهشناسى و مطالعات اجتماعى، مىتوان در

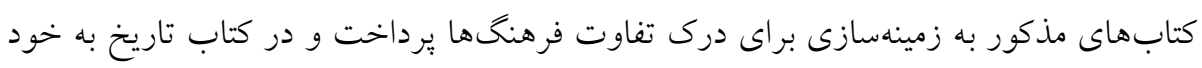

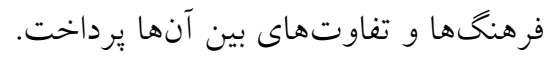

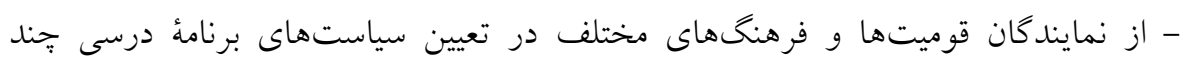
فرهنخى دعوت شود. - همجنين از كتاب جغرافيا در جهت شناساندن محلهاى جغرافيايى زندكى اقوام مختلف مىتوان استفاده كرد.

منابع - حكيم زاده، رضوان و كيامنش، عليرضا و عطاران، محمد (1/1). (اتحليل محتواى كتابهاى درسى دوره راهنمايى با توجه به مسائل و مباحث جهانى در حوزه برنامهٔ درسى")، فصلنامٔ مطالعات برنامئ درسى، سال دوم، شماره 0.

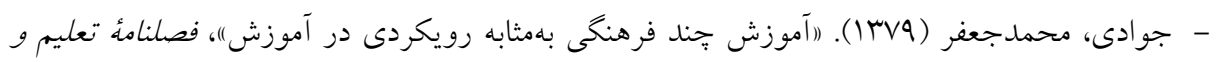

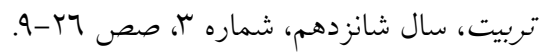

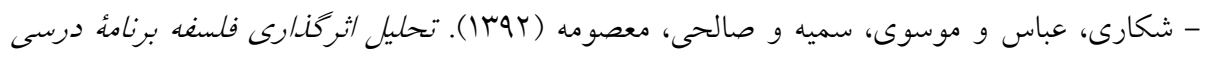

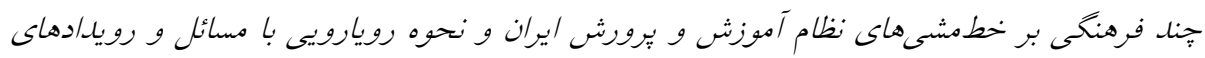


مؤلفهاى آموزش جند فرهنگى و تحليل آن در...

آن. جهارمين همايش ملى انجمن فلسفه تعليم و تربيت ايران: مبانى فلسفى تحول در نظام آموزش و و

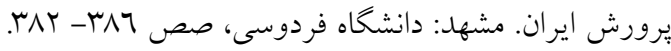

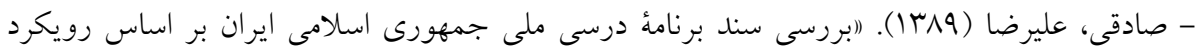

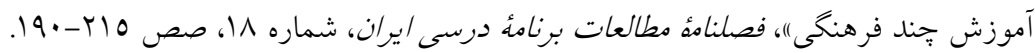

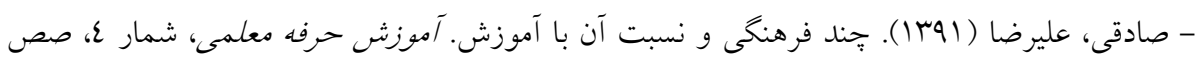
$r v-r \varepsilon$

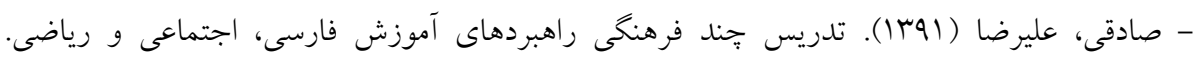

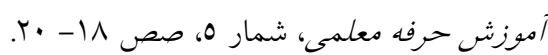
- عزيزى، نعمت و الله بلند همتان، كيوان و سلطانى، مسعود (

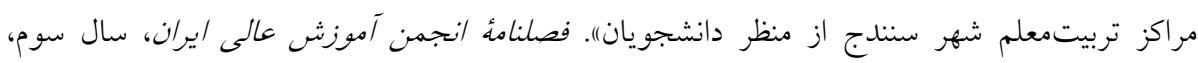
شماره T.

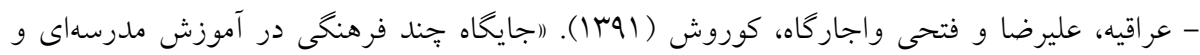

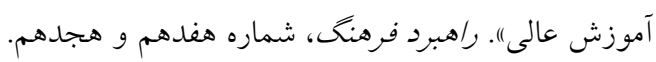

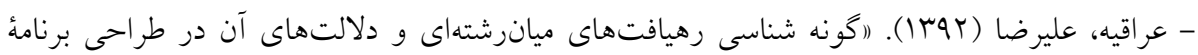

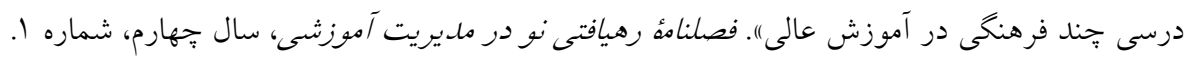

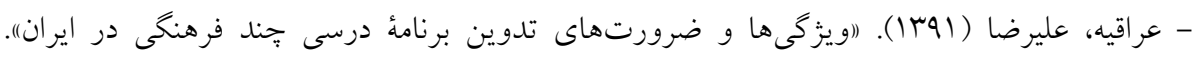
راهبرد فرهنخ، شماره هفدهم و هجدارهم.

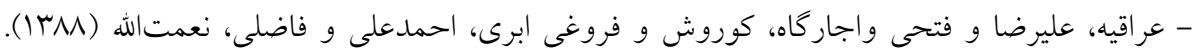

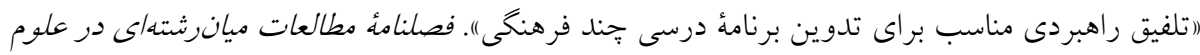

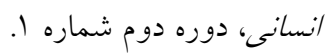

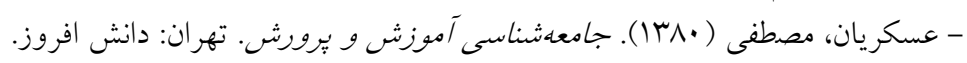

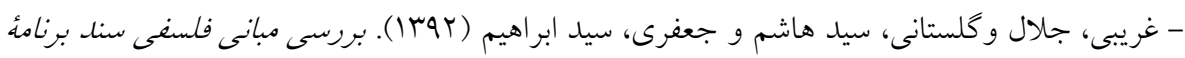

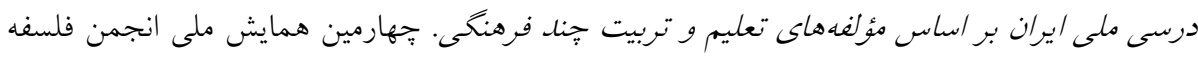

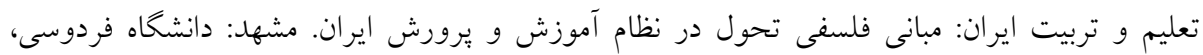
صص

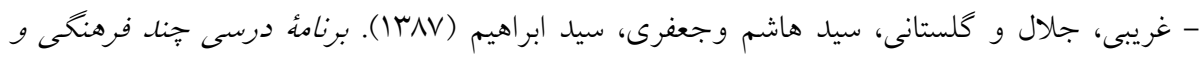

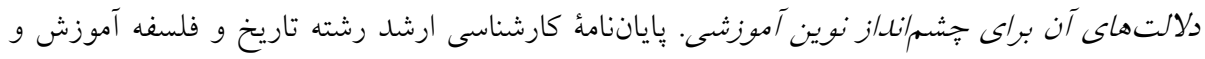
يرورش، دانشكده علوم تربيتى دانشخاه اصفهان.

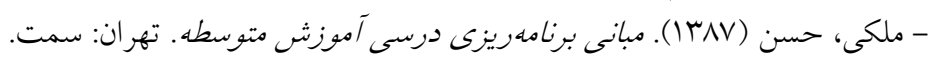

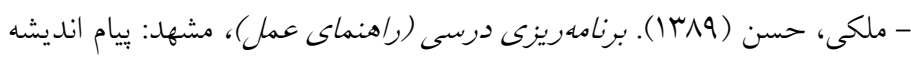

-ASCD (1994). An Introduction to Multicultural Education. Boston: Pearson, Allyn \& Bacon Fourth Edition. 
-Arvin. M. A (2001). Cultural Diversity and Education: Foundations, Curriculum and Teaching. Boston: Pearson, Allyn \& Bacon, 2001, 5th edtion 2006

-Banks, J. A. (2003). Teaching literacy for social justice and global citizenship. Language Arts, 81(1), 18-19.

-Banks, C. A. \& Banks, J. A. (1995). Equity pedagogy: An essential component of multicultural education. Theory into Practice, 34, 152-158

-Banks, J.A (1999). An Introduction to Multicultural Education (2 ${ }^{\text {nd }}$ ed) Boston: Allyn and Bacon Baptiste

-Delpit, L (1992). Education in a multicultural society: Our future's greatest challenge. Journal of Negro Education.61

-Hilliard, A.G. III (1991-92). Why we must pluralize the curriculum. Educational Leadership

-Jenks, C. Et al. (2001) approaches to multicultural education in preservice teacher education: philosophical frameworks and models for teaching. Human sciences press, Inc. 